\title{
Dietary Effect of Soybean (Glycine max) Products on Gut Histology and Microbiota of Fish
}

\author{
Daniel L. Merrifield ${ }^{1}$, Rolf Erik Olsen², \\ Reidar Myklebust ${ }^{3}$ and Einar Ring $\varnothing^{4^{*}}$ \\ ${ }^{1}$ Aquaculture and Fish Nutrition Research Group, The University of Plymouth, \\ 2Institute of Marine Research, Matre Aquaculture Station, Matredal, \\ ${ }^{3}$ Molecular Imagining Centre (MIC), Institute for Biomedicine, \\ University of Bergen, Bergen, \\ ${ }^{4}$ Norwegian College of Fishery Science, Faculty of Biosciences, \\ Fisheries and Economics, University of Tromsø, \\ Breivika, \\ ${ }^{1}$ UK \\ 2,3,4Norway
}

\section{Introduction}

On a global scale, fisheries landings have remained constant at about 90 million tons of fish per annum for the last decade whereas aquaculture output has been increasing at a rate of around $8 \%$ per annum and now supplies about 65 million tons (FAO 2010). Indeed, more than half of the fish products produced for human consumption come from commercial aquaculture. To sustain high rates of increased production, a matching increase in the volume of fish feeds is required. In 2009, compound aquafeed useage was ca. 30 million tons but this is expected to more than double by 2020 (FAO 2010; Tacon 2010). Although this is only a small portion of global animal feed production (ca. 620 million tons) the very specific nature of aquafeeds, e.g. higher protein and lower carbohydrate levels compared to other animal feeds, results in special challenges as traditional sources of fish - protein (fishmeal; FM) and oil (FO) are not sustainable. Worldwide annual production of FM (about 6 million tons) and FO (less than 1 million tons) has remained fairly stable for the last 20 years. FM and FO are produced from designated pelagic fisheries, mainly from the Atlantic, Chile and Peru. Efforts are constantly underway to ensure that these marine fisheries on which FM and FO depend remain sustainable and are not over-exploited. FM and FO are also produced from trimmings, offal and/or by-catch, although to a limited extent. Considering the known benefits of seafood, as a rich source of omega-3 fatty acids, in regards to human health (e.g. cardiovascular health, brain development, lowering cholesterol and blood pressure etc) the continued provision of this protein source is essential.

As there will be a limitation in global supplies of FM and FO in the near future sustainable alternatives must be explored. Soybean meal (SBM) and soybean oil (SBO) are considered to 
be suitable alternatives for the partial replacement of FM and FO and indeed are utilised in commercial aquafeeds. However, even when heat-treated, standard (solvent-extracted) and full-fat SBM-containing feeds supplemented with limiting amino acids, can lead to decreased growth in salmonids (Davies \& Morris, 1997). More specifically, dietary SBM inclusion causes lower feed intake, weight gain, fecal dry matter, and energy and fat digestibilities in all salmonid species studied (Krogdahl et al., 2003). Dehulled SBM as the sole protein source may lead to growth arrest and increased mortality in rainbow trout Oncorhynchus mykiss (Walbaum) (Rumsey et al., 1994). Full-fat SBM, however, appears to support better growth than solvent-extracted SBM in rainbow trout (Olli \& Krogdahl, 1994) and Atlantic salmon Salmo salar (Olli et al., 1994 b). Dehulled, solvent-extracted SBM causes similar negative effects on growth and nutrient digestibility in Atlantic salmon as SBM produced from hulled soybeans (Olli et al., 1994 b). White flakes, which are dehulled, moderately toasted solvent-extracted SBM, has been reported to cause similar reductions in growth, feed efficiency ratio, and nutrient digestibilities as standard SBM in Atlantic salmon (Refstie et al., 2005).

Thus, the change from FM and FO to soybean products presents several metabolic and health challenges for the farmed fish. When using high dietary levels of plant derived materials, particularly those derived from soybean, it is important to consider the impacts on gut microbiota and gut histology as the gastrointestinal (GI) tract can be one of the important infection routes for some pathogens in fish.

\section{Effect of soybean products on gut histology}

The primary purpose of the digestive tract is to digest foodstuffs into molecules suitable for absorption via the various transport mechanisms of the epithelial border cells of the GI sections. In essence, the fish GI tract is a tube-like structure that varies in complexity depending on the various feeding habits of the species. It can be subdivided into the mouth, oesophagus, stomach, pyloric ceaca, mid intestine, distal intestine and the rectum; however, not all of these distinctive regions are present in all fish. According to the early work of Suyehiro (1942), stomachs (if present) are classified into five categories according to their appearance: I - shape, $\mathrm{U}$ - shape, V - shape, $\mathrm{Y}$ - shape and $\Gamma$ - shape. Distal to the stomach, in the mid gut region, some fish have pyloric ceaca. These finger-like pouches can be completely absent or present in numbers ranging from few (e.g. flounders) to more than 1000 (e.g. gadoids) (Suyehiro, 1942; Olsen \& Ringø, 1997). Distal to the pyloric ceaca is the intestine which also varies in physiology across fish species. Typically, the GI tract of carnivorous fish species is short, often less than one body length long, whereas the GI tract of herbivorous and omnivorous fish species is much longer and can be found to be greater than 20 times the body length (Suyehiro, 1942; Olsen \& Ringø, 1997). Distinctive physiological differences are also observed between fresh water and marine species. The surface cells exposed to the luminal contents are the enterocytes, which with their microvilli structures, comprise the epithelial brushborder. Between the epithelial cells goblet cells excrete a continuous layer of mucus which forms an effective protective barrier. Beneath the inner epithelium we find the cellular connective tissues which comprise the lamina propria and the submucosa. Beyond the submucosa lie a circular muscular layer and a longitudinal muscular layer. Finally, the serosa forms the outer layer of the GI tract.

From an electron microscopy (EM) point of view, the GI tract is a fascinating organ as illustrated in Figure 1. 

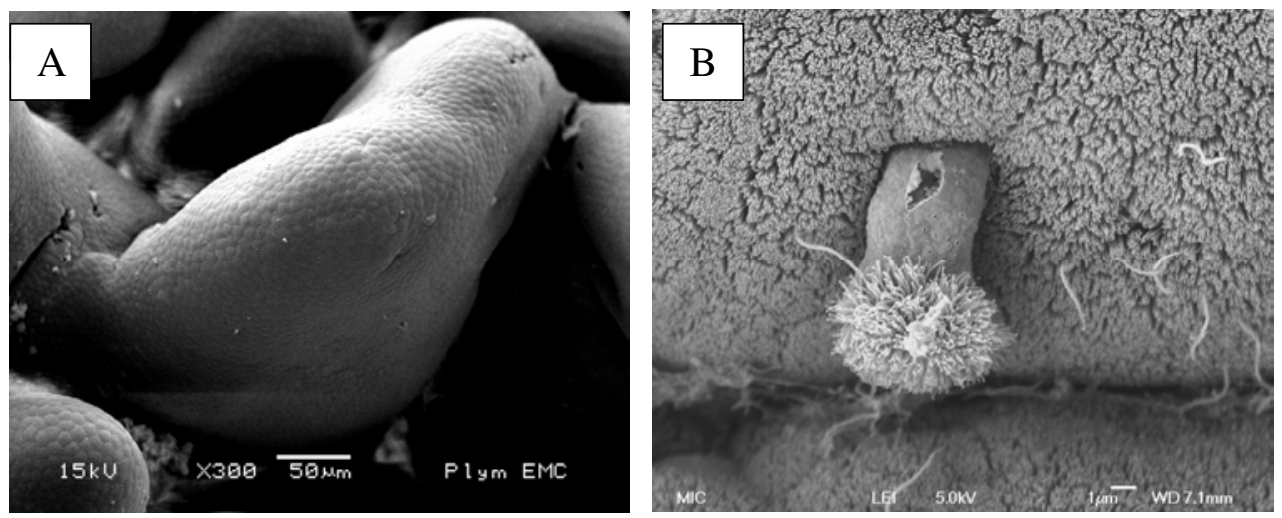

Fig. 1. A) Scanning electron microscopy (SEM) micrograph of mucosal folding (villi) from rainbow trout (Merrifield \& Dimitroglou unpublished data). B) SEM micrograph of a dead cell rejected by Atlantic salmon intestine (Myklebust, Olsen \& Ringø unpublished data).

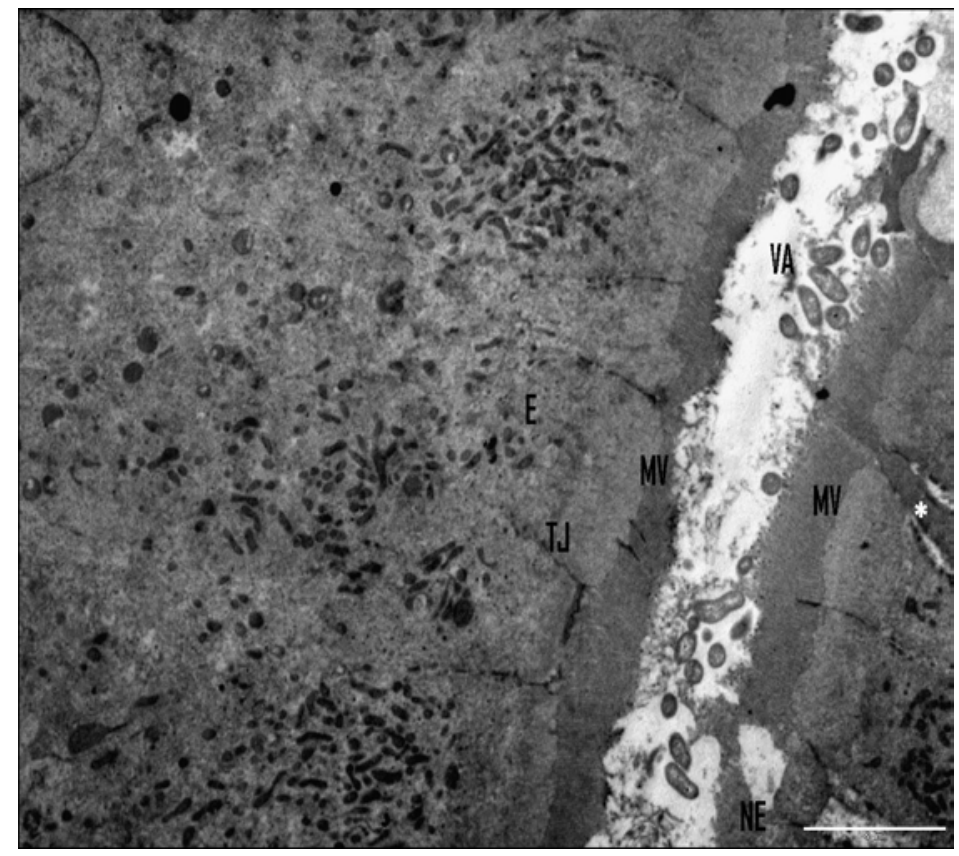

Fig. 2. Transmission electron microscopy (TEM) micrograph of the anterior intestine (mid gut) of rainbow trout exposed to $V$. (L.) anguillarum (VA). Clear signs of tissue damage are characterised by necrotic enterocytes (NE), disorganised microvilli and irregular and deteriorated tight junctional complexes (TJ) resulting in intracellular spaces $\left(^{*}\right)$. E = enterocyte. Scale bar $=5 \mu \mathrm{m}$. After Harper et al. (2011).

The GI tract of fish is considered as one of the major infection routes for some pathogens and indigenous intestinal bacteria (Groff \& LaPatra, 2000; Ringø et al., 2003; Birkbeck \& 
Ringø, 2005; Harikrishnan \& Balasundaram, 2005; Ringø et al., 2007; 2010a). Indeed, numerous studies have reported that exposure of the epithelium to fish pathogens can result in severe tissue damage, characterised by necrotic enterocytes, deteriorated tight junctions, disorganised and damaged microvilli and damage to the lamina propria (Ringø et al., 2007). An example of the damage that can be visualised at the ultra structural scale with transmission electron microscopy (TEM) is shown in Figure 2, where the midgut of rainbow trout has been exposed to Vibrio (Listonella) anguillarum, the causative agent of vibriosis. When discussing the inclusion of soybean products in commercial diets, it is of high importance to evaluate the effect on gut histology by both light microscopy (LM) and EM (Ringø et al., 2001; 2003; 2007; Harper et al., 2011) because structural and functional changes in the intestine may explain deleterious effects of SBM on nutrient utilization and disease resistance.

\subsection{Soybean meal}

SBM is one of the most commonly used protein sources in aquafeeds due to its high protein content and favourable amino acid profile. However, even when heat-treated and supplemented with limiting amino acids, full-fat as well as defatted (standard; hexaneextracted), SBM rich feeds can lead to decreased growth, lower feed intake and reduced energy and lipid digestibility in salmonid species. Using dehulled SBM as the sole protein source has been reported to reduce growth performance and increase mortality in rainbow trout. These SBM products also cause an inflammatory response in the distal intestine (enteritis) of salmonids, characterised by changes in absorptive cells, increased presence of inflammatory cells, endocytic blocking, shortening of villi and disruption of microvilli, which may at least partially explain the effects on growth parameters and feed utilization. It is accepted that such effects are mediated, in part at least, by anti-nutritional factors such as soy saponins which disrupt the intestinal barrier by altering membrane permeability. Subsequently, these histological and morphological changes in the intestine can increase susceptibility to bacterial infection.

Morphological changes evaluated by LM in the distal intestine (DI) of salmonids (Figure 3) are caused by dietary inclusion of full-fat as well as solvent-extracted SBM, with and without hulls (Baeverfjord \& Krogdahl, 1996; Aslaksen et al., 2007). These morphological changes in salmonids, known as enteritis, have been described as shortening of the simple and complex mucosal folds with a widening of the central stroma (lamina propria) and submucosa, shortened microvilli of the brush border membrane and increased formation of microvillar vesicles, elevated number of goblet cells and a dramatic decrease or even absence of the normal supranuclear absorptive vacuoles in the enterocytes (van den Ingh et al., 1991; 1996; Baeverfjord \& Krogdahl, 1996). Generally, the lamina propria is widened with a profound infiltration of a mixed population of inflammatory cells such as lymphocytes, neutrophilic granulocytes, cells of monocytic lineage, including macrophages, eosinophilic granular cells, and diffuse IgM (Baeverfjord \& Krogdahl, 1996; Bakke-McKellep et al., 2000) as well as a mixed population of putative T-cells (Bakke-McKellep et al., 2007 a). Regarding the epithelial cells lining the mucosal folds, the number of cells in early stages of development are significantly increased, as are the number of cells undergoing cellular repair and programmed cell death (apoptosis) (Bakke-McKellep et al., 2007 b).

In their study on Atlantic salmon, Kraugerud et al. (2007) observed morphological changes in the distal intestine of fish fed $10 \%$ dietary defatted SBM for 4 weeks. These changes included shortening and fusion of the simple mucosal folds, widening of the lamina propria with increased cellularity, leucocytic cellular infiltration of the submucosa and lamina 


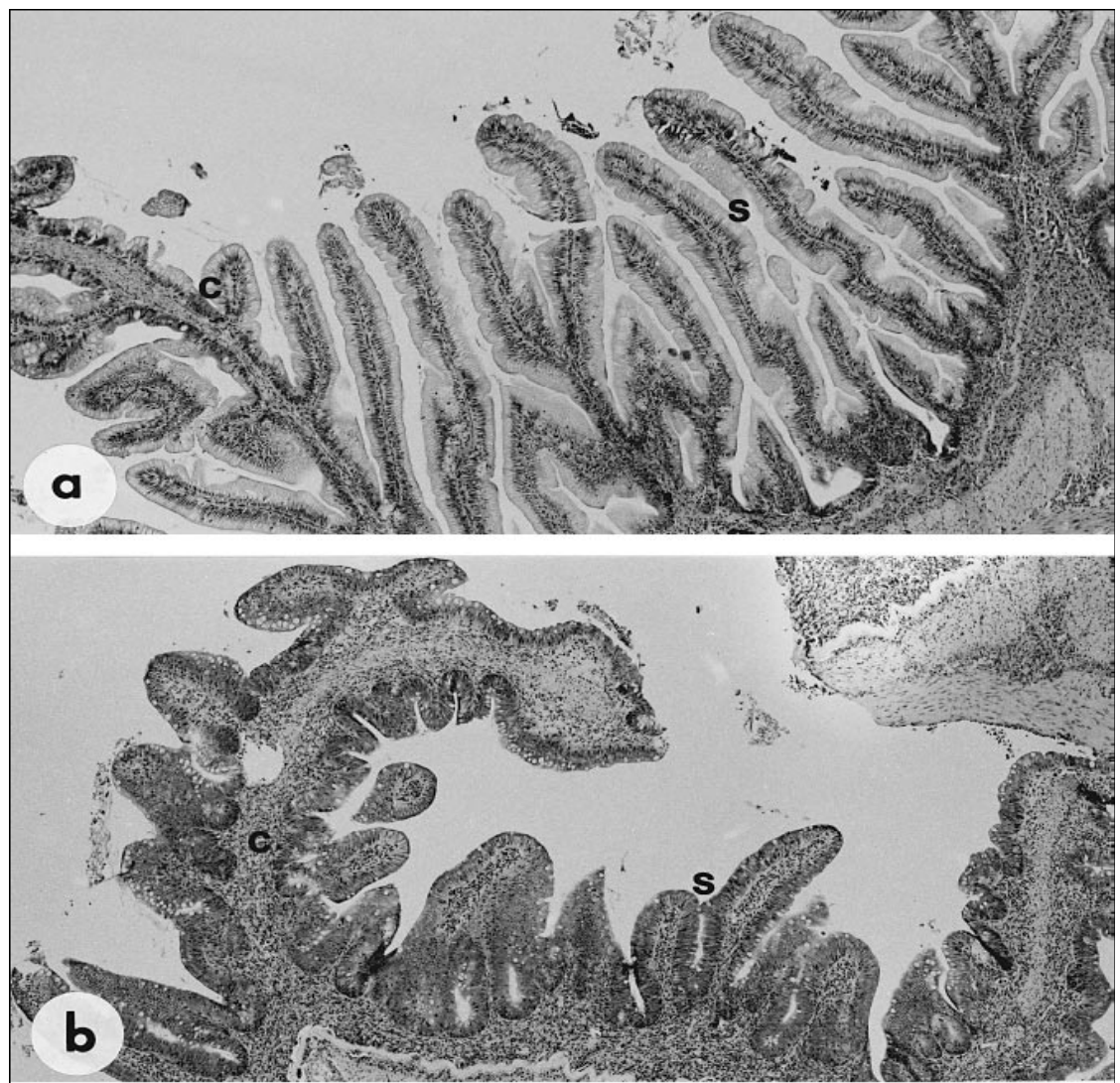

Fig. 3. LM image of the distal intestinal mucosa of Atlantic salmon fed a diet in which FM was the sole protein source (a) or a diet containing 33\% extracted SBM (b). In the latter, the lamina propria of the simple (s) and complex (c) intestinal folds are widened and infiltrated with a mixed population of leucocytes. The folds in (b) are also reduced in height compared to (a) (after Baeverfjord \& Krogdahl, 1996). X 400 magnification.

propria and reduced supranuclear vacuolisation with apical nuclear displacement within enterocytes. These significant morphological changes may affect the exchange of substances across the barriers including facilitated uptake of pathogenic bacteria. More, recently, Merrifield et al. (2009) observed the effect of replacing 50\% of FM with SBM (HiPro soya) on the intestinal epithelium of rainbow trout by using SEM (Figure 4).

After 16 weeks of feeding, EM revealed enteritis - like effects associated with SBM fed fish. Specifically, fish fed the SBM enriched diet displayed missing, damaged, deformed, shorter and thicker microvilli. Additionally, enterocytes appeared to be malformed and irregular. The general result of this study was significantly shorter (distal intestine) and less densely packed (proximal intestine) microvilli on the enterocyte surfaces of fish fed the SBM diet than fish fed the FM diet. This reduction of microvilli density consequently led to increased exposure of enterocyte tight junctions, which combined with necrotic enterocytes is likely to diminish the protective barrier of the intestinal epithelium (Merrifield et al., 

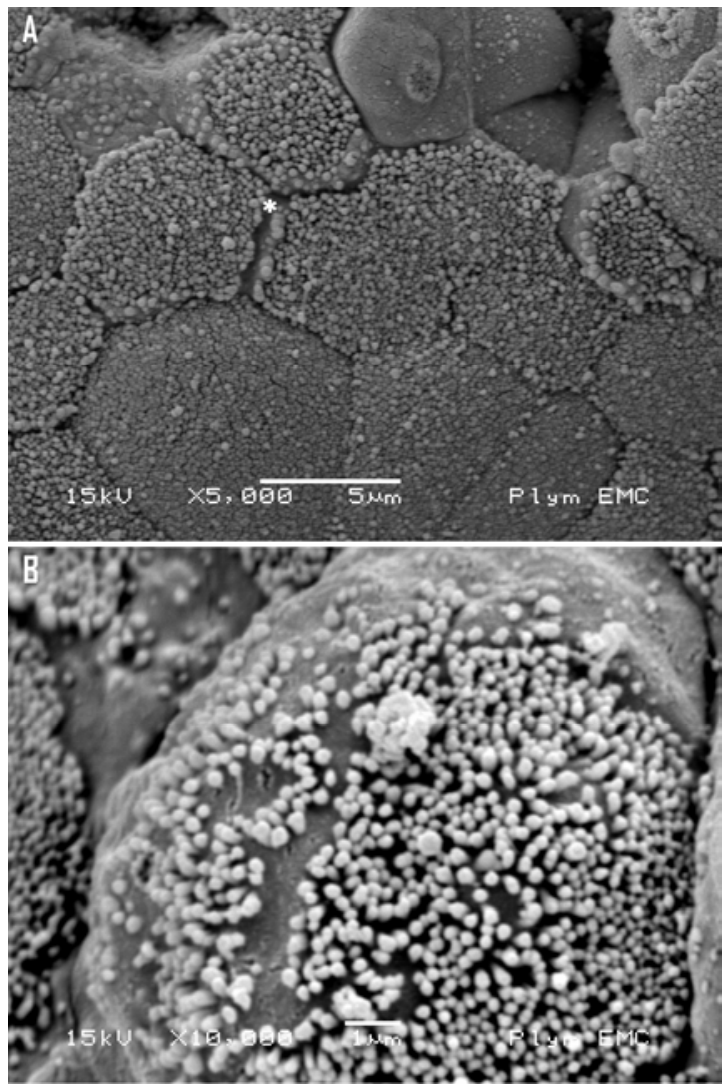

Fig. 4. SEM micrograph of the epithelial brush border of rainbow trout fed a SBM rich diet for 16 weeks. SBM fed fish display irregular enterocyte formations with sparse and irregular microvilli which consequently exposes tight junctions between the enterocytes $\left(^{*}\right)$ to luminal contents. Scale bars $=5 \mu \mathrm{m}(\mathrm{A})$ and $1 \mu \mathrm{m}$ (B). After Merrifield et al. (2009).

2009). Such enteritis effects have routinely been described in fish with the use of light microscopy (for review see Krogdahl et al., 2010) but considerably fewer studies have utilised electron microscopy to observe ultrastructural changes (Urán et al., 2008 a; Merrifield et al., 2009; Dimitroglou et al., 2010). Such histological and morphological changes which result in damaged enterocytes and exposed intracellular tight junctions may help explain previous observation of increased susceptibility of SBM fed fish to pathogenic infection (Krogdahl et al., 2000).

It is generally accepted that this type of damage is due to the presence of various antinutritional factors present in SBM. For example, soy saponins, which disrupt the intestinal barrier by altering membrane permeability which is suggested to trigger the inflammatory process (Knudsen et al., 2007). Recent investigations also suggest that this enteritis effect is related to (either as a cause or effect) the blocking of enterocyte endocytic uptake mechanisms (Urán et al., 2008 b; Rombout et al., 2011). Although the molecular signalling pathways involved in the manifestation of enteritis have not been fully elucidated some 
information is available; the expression of pro-inflammatory genes (IL-1 $\beta$ and TNF-a1) have been reported to be up-regulated in the intestinal intraepithelial leucocytes of fish fed dietary SBM (Urán et al., 2008 a).

From the plethora of studies available it has become generally accepted that there are variations in the sensitivity of different fish species to dietary SBM. Due to their carnivorous feeding habits salmonids are less well adapted to plant based ingredients and so species such as Atlantic salmon and rainbow trout (although to a lesser extent than Atlantic salmon) are highly sensitive to dietary SBM. On the contrary, numerous studies have reported no morphological disruptions of the intestinal tract of other fish species, such as Atlantic cod (Refstie et al., 2006), Atlantic halibut (Grisdale-Helland et al., 2002), gilthead seabream Sparus aurata (Bonaldo et al., 2008, Dimitroglou et al., 2010), European sea bass Dicentrarchus labrax (Bonaldo et al., 2008), cobia Rachycentron canadum (Romarheim et al., 2008) and Egyptian sole Solea aegyptiaca (Bonaldo et al., 2006), fed dietary SBM. These observations are somewhat strange as some of these species are also highly carnivorous.

However, a recent study by Urán and colleagues (2008 a) reveals important information regarding the time dependent nature of the morphological manifestations of enteritis in fish. This study revealed the onset of histological changes, and related inflammatory molecular markers, in carp after 1-3 weeks feeding on dietary SBM (20\% dietary inclusion). However, after 4-5 weeks these morphological changes appeared to subside in tandem with the increase of TGF- $\beta$ (TGF- $\beta$ is an anti-inflammatory protein involved in cellular differentiation and proliferation) mRNA transcripts from intraepithelial leucocytes. This indicates that carp display an adaptive period which may have important connotations to the results from other studies which have reported no histological disruptions in the gut of non-salmonid fish because the previous studies on non-salmonid species have assessed the intestinal morphology after $\geq 6$ weeks feeding on SBM diets. Future time dependent studies are necessary to see if such short term enteritis effects occur in other fish species.

\subsection{Soybean oil}

SBO is extracted from the seeds of the soybean. Regardless of origin, plant oils are deficient in the typical marine long chain highly unsaturated fatty acids (HUFAs) arachidonic acid (ARA, 20:4n-6), eicosapentaenoic acid (EPA, 20:5n-3) and docosahexaenoic acid (DHA, 22:6 $n-3)$. The composition of other fatty acids will vary with plant species. One of the predominant plant oils produced and used in aquafeeds, SBO, is rich in 18:2 n-6 (52 \%), 18:1 (24\%) and 16:0 (11\%) but due to its deficiency in long chain HUFAs SBO and other plant oils are typically blended with FO when incorporated into fish diets.

In marine fish, the most predominant effect of increasing plant oils, including SBO, in the diets is the reduction of cellular EFA content and some alteration in membrane composition. In salmonids, including plant oils will not only affect membrane composition, but will also alter the ratio of n-6 / n-3 $C_{20}$ PUFA, which may have pronounced effects on immune functions and eicosanoid production. With the inclusion of plant oils into aquafeeds, fish are faced with several challenges some of which will affect intestinal health and function. One of the most striking effects is the massive accumulation of lipid droplets in enterocytes of fish species such as Arctic charr (Olsen et al., 1999; 2000), gilthead seabream (Caballero et al., 2003), rainbow trout (Caballero et al., 2002; Olsen et al., 2003) and Atlantic salmon (Olsen et al., unpublished data) fed high levels of plant oils. The accumulations may amount to more than $60 \%$ of cellular volume which hampers gut functions (Figure 5). Although there is still some controversy with regard to the direct cause of these observations (Oxley et al., 2005; 
Caballero et al., 2006; Oxley et al., 2007) the condition appears to be related to the impairment of lipoprotein synthesis within the enterocytes.

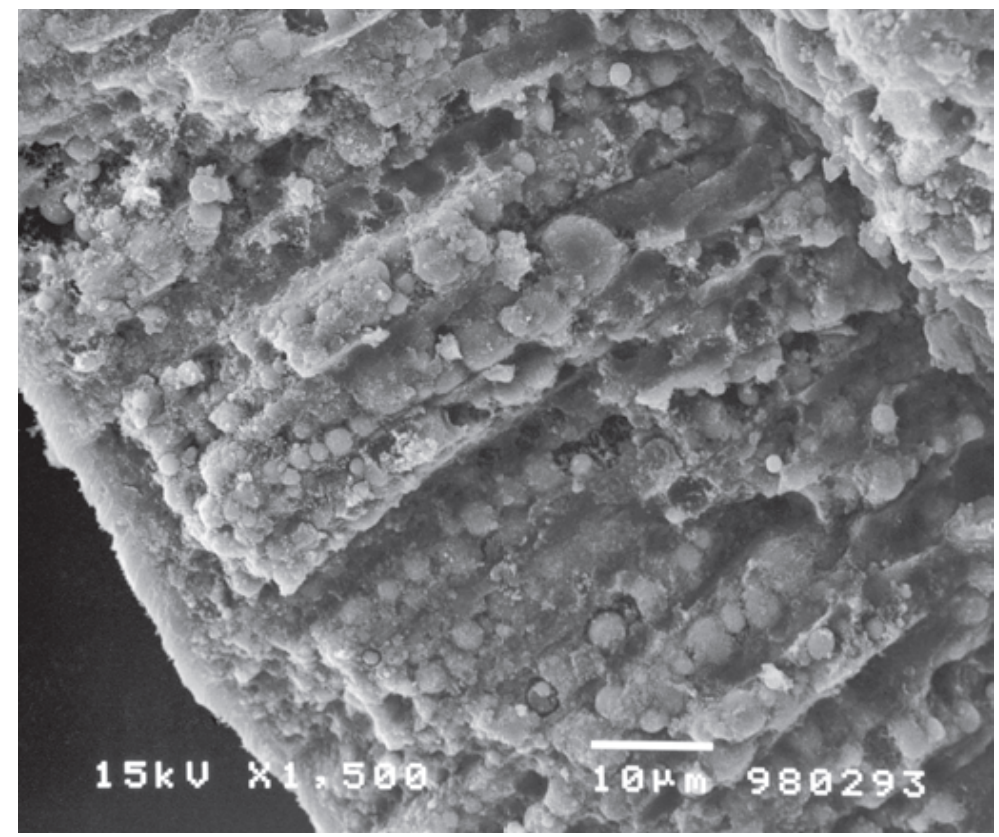

Fig. 5. SEM micrograph depicting the cross section of midgut enterocytes from Arctic charr fed an experimental diet containing SBO as the sole lipid source. Note the significant accumulation of lipid droplets in the enterocytes. After Ringø \& Olsen (2008).

In Atlantic salmon substituting up to $100 \%$ of the added FO (note some FO is present in FM) with SBO did not increase leukotriene $\mathrm{B}_{4}\left(\mathrm{LTB}_{4}\right)$ or type $\mathrm{E}_{2}$ prostaglandin $\left(\mathrm{PGE}_{2}\right)$ (proinflammatory mediators) production of head kidney macrophages during in vitro culture with 20:4 n-6 added to the culture medium, except at $5^{\circ} \mathrm{C}$ rearing temperature (Gjøen et al., 2004). Phagocytic activity was also unaffected and based on these results the authors concluded that Atlantic salmon seems to tolerate a diet with only SBO as lipid source, without any detrimental effects on growth and immune functions. In a feeding trial with rainbow trout fed purified diets supplemented with only SBO, linseed oil or FO for 9 weeks no differences in serum complement or lysozyme activity were observed (Kiron et al., 2004).

The effect of SBO on disease resistance in challenge experiments is less well studied and the results are somewhat conflicting. In a long-term feeding study using SBO and FOs, Waagbø et al. (1993) showed that Atlantic salmon fed high levels of FOs had better survival when infected with Aeromonas salmonicida (the causative agent of furunculosis), despite the fact that head kidney macrophage phagocytosis and bacterial killing was reduced in these fish (IL-1 and serum hemolytic activity was unaffected). In contrast to these results, Gjøen et al. (2004) reported no differences in Atlantic salmon susceptibility to infection by A. salmonicida, while Lødemel et al. (2001) reported that Arctic charr fed diets supplemented with SBO and challenged with $A$. salmonicida showed elevated survivability compared to fish fed a FO based diet $(\mathrm{SBO}=20 \%$ mortality $v \mathrm{~S} \mathrm{FO}=48 \%$ mortality $)$. 


\section{Effects of soybean products on gut microbiota}

The gut microbiota of fish constitutes a great number of cells and these cells and their metabolites play important roles in host digestive function, gastric development, mucosal tolerance, immunity and disease resistance. In fact, in the absence of gut microbiota the digestive tract fails to differentiate fully, lacks brush border intestinal alkaline phosphatase activity, presents immature patterns of glycan expression, displays reduced epithelial proliferation and a reduction of goblet and enteroendocrine cells (Rawls et al., 2004; Bates et al., 2006). It is of utmost importance for the health of the animal that microbes that improve gut function and the immune apparatus dominate these microbial communities. Therefore, great efforts have been made to find dietary supplements that ensure that benign or beneficial microbes dominate the gut microbiota of fish (Merrifield et al., 2010; Ringø et al., 2010 b; Dimitroglou et al., 2011).

As is the case with terrestrial animals, the gut microbiota of fish is classified as autochthonous or indigenous, when they are able to adhere and colonize the host's gut epithelial surface, or allochthonous, when they are incidental visitors in the GI tract, and are expelled after some time without colonizing (Ringø \& Birkbeck, 1999; Ringø et al., 2003; Kim et al., 2007). Compared to the numerous studies describing the dietary effect on fish gut microbiota (Ringø et al., 1995; Austin, 2006; Merrifield et al., 2010) relatively little information is available about the effects of SBM and SBO (Ringø et al., 2002; Hekkinen et al., 2006; Ringø et al., 2006; Bakke-McKellep et al., 2007 b; Ringø et al., 2008; Merrifield et al., 2009; Cai et al., 2011).

\subsection{Soybean meal}

While much effort has focused on evaluating the extent of SBM induced histological damage the effect on the gut microbiota of fish is not so well documented. This is partly because of our lack of understanding of the importance of the gut microbiota in the past but as our awareness of this complex microbial ecosystem has grown so too has our interest in the factors that might impact or disrupt these communities.

As a result there are now several studies which have sought to assess the impact of dietary SBM on fish gut microbiota. To our knowledge, the first is that of Hekkinen et al. (2006), who utilised both culture-dependent and molecular methods (culture-independent) to observe the effect of dietary SBM (hexane extracted; included at a dietary level of $45 \%$ ) on the gut microbiota of rainbow trout in comparison to a FM control group. After 8 weeks feeding on the experimental diets the total culturable aerobic, aerotolerant culturable lactic acid and total culturable anaerobic bacterial levels (CFU g-1) were at least one log scale lower in the SBM fed fish than the FM fed fish. Some tentative identifications of bacterial isolates revealed that some bacterial genera/groups may have been specifically affected; compared to the FM group a clear reduction of Lactobacillus spp. ( $\mathrm{FM}=8.57 \%, \mathrm{SBM}=0 \%$; as a percentage of isolates identified) and Sphingomonas spp. ( $\mathrm{FM}=31.4 \%, \mathrm{SBM}=3.7 \%)$ isolates were observed in the SBM group. Conversely, an increase of Bacillus spp. (FM = 0\%, SBM = $7.4 \%)$ and Chryseomonas spp. $(\mathrm{FM}=5.7 \%, \mathrm{SBM}=22.2 \%)$ were isolated from the SBM group. However, as this was not a comprehensive study (only 62 isolates were identified during the trial) and identification was based on phenotypic and biochemical characteristics this data should be viewed with caution. Culture-independent analysis, length heterogeneity analysis of PCR amplified 16S rRNA (LH-PCR), from a secondary 18 week feeding trial also suggested that dietary SBM induced qualitative changes in the microbial communities. 
Contrary to the findings of Heikkinen et al. (2006), a more recent study by Merrifield et al. (2009), did not reveal any differences in the in total culturable aerobic levels when comparing the autochthonous and allochthonous gut populations of rainbow trout fed a FM control diet with those fed a SBM diet (SBM inclusion at 32\%) for 16 weeks. The reason for the differing outcomes is somewhat unclear but it may be related to 1] the different feeding duration (8 weeks vs 16 weeks), 2] the different SBM inclusion level (45\% vs 32\%), 3] the different SBM characteristics (SBM with hulls vs dehulled HiPro with lower fibre and higher protein content), 4] the different culture conditions (plate count agar, $15^{\circ} \mathrm{C}, 21$ days vs trytone soya agar, $20^{\circ} \mathrm{C}, 7$ days) and/or 5] other differences in the experimental rearing trial. Despite this however, using partial $16 \mathrm{~S}$ rRNA sequence analysis, Merrifield and co-authors observed differences in microbial composition comprising the total viable populations (as illustrated in Figure 6). This could be generally characterised as lower levels of Aeromonas spp. and Vibrio spp., marginally higher levels Micrococcus spp. and a substantial increase in the allochthonous levels of a group identified as belonging to the order Actinomycetales (isolates could not be differentiated from Arthrobacter aurescens, Janibacter spp. and Streptomyces coelicolor) observed in the SBM group compared to the FM group. Additionally, a population of Psychorbacter spp. (Psychrobacter spp. PRwf-1, P. cryohalolentis or P. arcticus) was present only in the SBM fed group. It was also observed that dietary SBM could affect the levels of indigenous yeast in the gut. Yeast levels, tentatively identified as Saccharomyces spp., increased from $8.7 \%$ to $39.3 \%$ (FM vs SBM; as a proportion of the culturable community), $17.3 \%$ to $19.3 \%, 12.7 \%$ to $52.7 \%$ and $14.0 \%$ to $48.7 \%$ in the anterior mucosa, posterior mucosa, anterior digesta and posterior digesta, respectively. It was hypothesised that this might be a direct result of fermentable carbohydrates provided by SBM. Oligosaccharides, such as stachyose and raffinose, typically constitute about $4-5 \%$ of SBM by dry weight. Raffinose and stachyose consist of fructose, glucose and galactose and many genera of yeast, including Saccharomyces, are able to ferment various sugars, including glucose and galactose; hence, an increase in yeast numbers may be a result of increased available sugars.

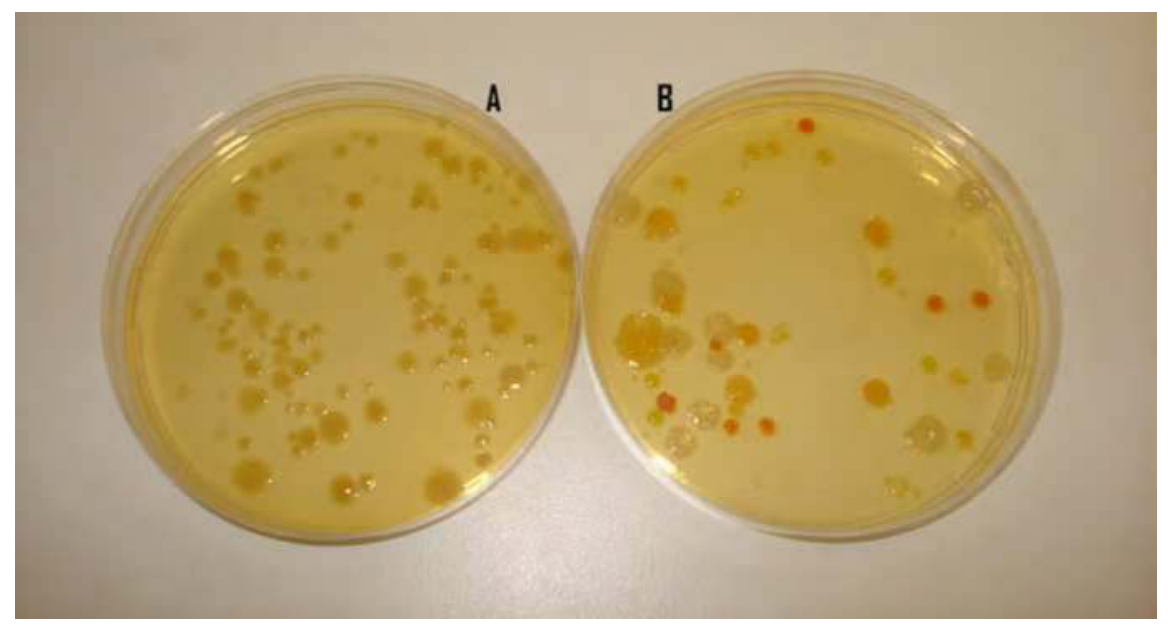

Fig. 6. Tryptic soya agar (TSA) plates showing culturable allochthonous bacteria isolated from the posterior intestine of rainbow trout fed FM (A) and SBM (B) diets. 
EM confirmed the presence of complex autochthonous bacterial populations in close association with of the mucosal brushborder of both FM and SBM fed rainbow trout but no distinct colonisation patterns or differences between dietary groups was observed. Due to the reduced density of enterocyte microvilli caused by dietary SBM the exposure of tight junctions to brushborder bacterial populations was increased which may have negative connotations towards defensive barrier function to opportunistic bacterial populations (Figure 4).

These findings are somewhat similar to those of Bakke-McKellep et al. (2007 b) who also reported higher levels of yeast in SBM fed fish. Bakke-McKellep et al. (2007 b) investigated the microbiota of seawater-adapted Atlantic salmon fed diets containing FM as the sole protein source or diets containing $25 \%$ dehulled and extracted and toasted SBM. After 3 weeks the culturable aerobic autochthonous mid intestine, autochthonous distal intestine and allochthonous distal intestine bacterial levels were higher in the SBM fed salmon compared to the FM fed salmon. Diet dependent differences in the diversity of bacterial strains identified were also observed. The number of different genera and strains identified were similar in the SBM fed (26) and FM fed (24) fish but the number of some isolated lactic acid bacteria (Marinilactibacillus psychrotolerans and Carnobacterium (piscicola) maltaromaticum) was higher in the FM fed salmon. However, Brevibacterium and Enterococcus spp. were detected in the SBM group but not in the FM group.

In a later experiment post-smolt Atlantic salmon were fed a FM diet or diets containing $14.7 \%$ soy fibre (N100), $14.7 \%$ extruded soy fibre (E100) or $43.6 \%$ SBM (with hull, hexane extracted and toasted) for 4 weeks (Ringø et al., 2008). Culturable allochthonous and autochthonous bacterial levels within the mid and distal intestine were determined and 16S rRNA sequence analysis was used to identify isolates. Contrary to the findings of BakkeMcKellep et al. (2007 b) no significant differences were observed between viable counts from the intestinal samples of the respective FM and soy fed groups. Differences between the bacterial groups were observed which appear to verify some of the findings observed by Bakke-McKellep et al. (2007 b). Specifically, Carnobacterium spp. were sensitive to the inclusion of dietary SBM; high levels of Carnobacterium spp. were identified as both autochthonous and allochthonous populations with the distal intestine of fish fed the FM diet but were completely absent from both sampling points of the mid and distal intestine of the SBM fed fish. In contrast, Bacillus spp. were the greatest genera isolated from the digesta (allochthonous) of the FM fed fish (log 5.8 CFU g-1) but were completely absent from both the mid and distal digesta of the SBM fed fish. Several other bacterial species, present at lower levels, were identified as present in one of the dietary groups but absent in the other. Some information is also available on the effect of dietary SBM on the culturable intestinal bacterial levels (Refstie et al., 2006; Ringø et al., 2006) and composition (Ringø et al., 2006) of Atlantic cod. These studies compared the allochthonous and autochthonous bacterial populations within the foregut, mid gut and hindgut chamber of cod fed a FM diet with cod fed a diet containing 24.6\% SBM (dehulled and solvent extracted) or $21.4 \%$ bioprocessed extracted SBM (BPSBM; the bioprocessing reduces the oligosaccharide and phytic acid content, concentrates the protein, and eliminates anti-nutritional factors). Five of the six intestinal bacterial populations investigated were significantly affected by dietary SBM but only three were affected by dietary BPSBM (Refstie et al., 2006). Compared to the FM group, the autochthonous culturable levels were higher in all three intestinal regions whereas the allochthonous levels were significantly lower in the foregut and midgut of the SBM fed group. The autochthonous foregut, allochthonous foregut and allochthonous mid gut levels 
were all significantly higher in the BPSBM group than the FM group. The allochthonous distal population remained unaffected by either dietary treatment.

Ringø et al. (2006) used standard biochemical methods and 16S rRNA sequencing analysis (425 isolates) to identify a total of 944 of the isolates derived from these intestinal sampling regions. The authors concluded that the intestinal tract of fish fed FM was dominated by Gram-positive bacterial genera (most notably Brochothrix spp., Carnobacterium spp. and unknown Gram-positive cocci) whereas Gram-negative bacteria (such as Chryseobacterium spp., unknown Gram-negative rods and a number of Psychrobacter and Psychrobacter - like spp.) were more frequently isolated from the fish fed the SBM and BPSBM diets. The diversity of Psychrobacter spp. was also greater in the SBM and BPSBM groups and several other strains (e.g. Acinetobacter johnsoni, Jeotgailbacillus psychrophilus and Jeotgalibacillus - like) were found to be uniquely present in the SBM group as a minor component of the community. Although no clear differences in carnobacterial levels were apparent (there were marginal differences which hinted at a lower frequency of isolation from the BPSBM fed cod) in vitro antagonism assays against $A$. salmonicida and $V$. (L.) anguillarum suggest that there might be differences in the carnobacteria antagonistic properties. For example, 57.8\% of Carnobacterium isolates from the FM group demonstrated antagonistic activity against one or both of the pathogens but only $33.3 \%$ of the SBM isolates were able to antagonise one or both of the pathogens and $38.5 \%$ of isolates from the BPSBM group inhibited the growth of A. salmonicida (none were effective against $V$. (L.) anguillarum). Although this was only a small scale preliminary investigation it may have relevance to previous observations of elevated disease susceptibility of fish fed SBM.

In contrast to the growing literature available on the effect of SBM on the gut microbiota of salmonid fish species relatively little is known about other fish species. This is likely because it has been generally accepted that non-salmonid fish species are less susceptible to enteritis and histological damage of the intestine as a result of dietary SBM inclusion. However, some information is available.

Dimitroglou et al. (2010) assessed the gut microbiota of gilthead seabream fed diets with or without mannan oligosaccharides (MOS) in both FM and SBM (solvent extracted, included at $31.3 \%$ ) diets. PCR-DGGE analysis revealed clear differences in the allochthonous microbial communities, reflected by cluster analysis from dendrograms (depicting low similarity between treatments) and by higher species richness (increased observable phylotypes; $\mathrm{FM}=14.5 \pm 0.7$ vs $\mathrm{SBM}=25.0 \pm 0.0$ ), microbial diversity (shannon weaver index; $\mathrm{FM}=2.65 \pm 0.05$ vs SBM $=3.17 \pm 0.01$ ) and higher similarity between replicates (SIMPER; $\mathrm{FM}=84.79 \%$ vs $\mathrm{SBM}=92.25 \%)$. Unfortunately, no phylotypes were sequenced so identification of sensitive species in the study remains unknown. However, the study revealed that dietary SBM had a greater effect on the gut microbiota than dietary MOS as MOS was shown to affect the microbial communities in the FM fed group but any potential for modulation in the SBM group was masked by the effect of SBM.

In contrast to the clear changes observed in gilthead seabream (Dimitroglou et al., 2010), Cai et al. (2011) observed no significant affect of dietary SBM (30\% inclusion) on the gut microbiota of silver crucian carp (Carassius auratus gibelio x Cyprinus carpio) after 3 weeks feeding. Total culturable aerobic, anaerobic, presumptive Aeromonas spp., presumptive E. coli, presumptive Clostridium perfringens and presumptive bifidobacteria levels remained unaffected by dietary treatment. Further molecular studies and identification of isolates are required to validate these findings. 
Despite the growing number of studies beginning to shed light on the effects of dietary SBM on the gut microbiota of fish, present information is largely based on cultured isolates. As is typically the case with microbial communities from the aquatic environment, the culturability of the gut microbiota of fish is inherently low; culturability of the gut microbiota of rainbow trout has typically been reported to be $3-50 \%$ (when using the following culture conditions - TSA, 7 days, 15C) (Spanggaard et al., 2000; Huber et al., 2004) or $18 \%$ (TSA, 10 days, $17 \mathrm{oC}^{\circ}$ ) (Navarrete et al., 2010), ca. 1\% in coho salmon Oncorhynchus kisutch (TSA, 10 days, $17{ }^{\circ} \mathrm{C}$ ) (Navarrete \& Romero, 2006) and $<1 \%$ in Atlantic salmon (TSA, 10 days, $17{ }^{\circ} \mathrm{C}$ ) (Navarrete et al., 2009). Therefore it is essential that culture-independent techniques be employed in future studies. As there is limited knowledge about the effect of soybean products on the largely unculturable proportion of gut microbiota, particularly anaerobic microbial communities which have yet to be studied, in the GI tract of various fish species, important questions are raised: is it possible to increase the population level of beneficial gut bacteria by inclusion of dietary soybean products and will these beneficial gut bacteria improve fish welfare? Indeed, it has been suggested that SBM-oligosaccharides may have potential to be utilised as prebiotics to fortify microbial balance and improve host health (Gibson et al., 2004).

Additional investigations need to extend to other important aquatic species as SBM is one of the commonly used plant proteins incorporated into aquafeeds (Gatlin et al., 2007). Furthermore, studies should focus on the autochthonous populations as these populations are in intimate contact with the host epithelium and are of high importance in terms of stimulating host inflammatory responses.

\subsection{Soybean oil}

It is generally accepted that dietary manipulation modulates the gut microbiota (e.g. BakkeMcKellep et al. 2007b; Merrifield et al., 2009; Dimitroglou et al. 2010) and several studies have observed sensitivity of the gut microbiota of fish to different dietary lipid levels (Lesel et al., 1989; Ringø \& Olsen, 1999) and different dietary plant oils (Ringø et al., 2002; Montero et al., 2006). However, to our knowledge only one study has assessed the effect of dietary SBO on the gut microbiome of fish. In their study with Arctic charr, Ringø et al. (2002) evaluated the effect of SBO on the autochthonous gut microbiota. The presence of autochthonous bacteria associated with the microvilli of fish fed the SBO enriched diet is demonstrated in Figure 7.

The bacteriological results of the study showed modulation of the gut microbiota by SBO as well as inter individual fish variations. Specific differences between the groups were the marginal elevation of the total culturable population (by over $\log 0.5 \mathrm{CFU} \mathrm{g}^{-1}$ ) in the SBO group and differences of the bacterial components comprising this community. For example, Acinetobacter spp. ( $\log 4.35 \mathrm{CFU} \mathrm{g}-1)$, Carnobacterium spp. (log $4.41 \mathrm{CFU}$ g-1), coryneforms (log $\left.4.59 \mathrm{CFU} \mathrm{g}^{-1}\right)$ and Kurthia spp. $\left(\log 4.29 \mathrm{CFU} \mathrm{g}^{-1}\right)$ were key components in all 5 fish replicates from the SBO group but were completely absent in all FO fed fish. Conversely, Aeromonas hydrohpila (log $3.85 \mathrm{CFU} \mathrm{g}^{-1}$, present in 5 fish) and Moraxella spp. (log $3.35 \mathrm{CFU} \mathrm{g}^{-1}$, present in 3 fish) were present in the FO fed fish but were absent in the SBO fed fish. The authors further evaluated the microbial communities after a challenge with Aeromonas salmonicida ssp. salmonicida (furunculosis). Post challenge the total viable bacterial levels in both dietary groups was reduced, however, the counts were reduced to ca. one $\log \mathrm{CFU} \mathrm{g}^{-1}$ lower in the SBO group than the FO group. Differences in the levels of certain microbial groups persisted after the challenge: Acinetobacter spp. and Carnobacterium spp. were present in the SBO fed charr but absent in the FO fed charr and Micrococcus spp. were present in the FO fed charr but absent in the SBO fed charr. 


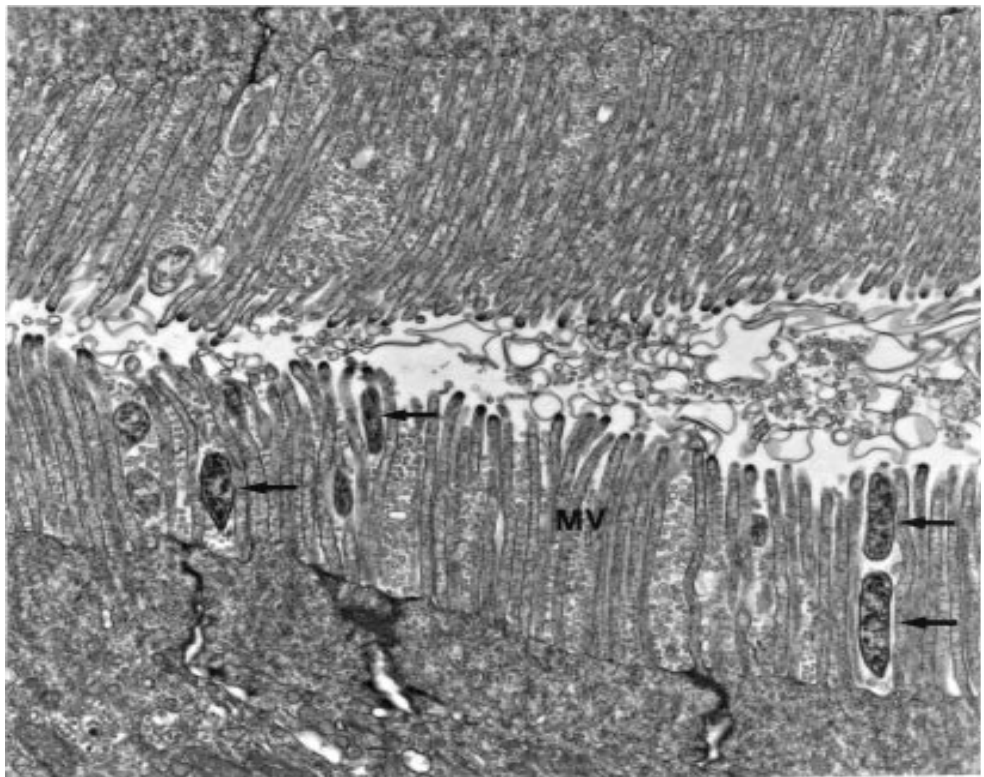

Fig. 7. TEM micrograph of the midgut of Arctic charr fed a diet containing SBO. Note the substantial numbers of bacteria (arrows) associated with the microvilli (MV) of the enterocytes. X 3,750 magnification. After Lødemel et al. (2001).

\section{Conclusion}

Even though numerous papers regarding the effect of dietary soybean products on the gut histology and gut microbiota of fish have been published in peer reviewed journals further investigations are needed. Using plant-based raw materials may have both advantages and disadvantages. Firstly, imbalanced plant based diets and noxious compounds such as antinutrients may impair fish immunity, maturation and functionality of the intestinal mucosa, the first line of defence and in particular damage the GI tract which is a port of entry for many pathogenic agents. Furthermore, endothermic and fish studies have shown atrophy of intestinal mucosa and a reduction in its absorptive and immunological capacity in response to high dietary SBM inclusion. Secondly, using the correct mixture of plant based additives, provides not only the option of limiting harm, but there is also an interesting possibility to enhance GI immunity and disease resistance. Current knowledge is however relatively limited in this regard. However, based on the likelihood that future aquaculture will have to rely on plant-based raw materials, it is strongly recommended that these topics should be given high priority in the years to come. Readers with special interest in the use of plant products in aquaculture are referred to the reviews of Gatlin et al. (2007), Barrows et al. (2008) and Krogdahl et al. (2010).

\section{Acknowledgment}

The authors wish to thank Glenn Harper for his technical expertise in EM which was vital in some of the studies cited in the present review. 


\section{References}

Aslaksen, M.A., Kraugerud, O.F., Penn, M., Svihus, B., Denstadli, V., Jørgensen, H.Y., Hillestad, M., Krogdahl, A., Storebakken, T. (2007). Screening of nutrient digestibilities and intestinal pathologies in Atlantic salmon, Salmo salar, fed diets with legumes, oilseeds, or cereals. Aquaculture 272, 541-555.

Austin, B. (2006) The bacterial microflora of fish, revised. The Scientific World Journal 6, 931945.

Baeverfjord, G., Krogdahl, A. (1996) Development and regression of soybean meal induced enteritis in Atlantic salmon, Salmo salar L., distal intestine: a comparison with the intestines of fasted fish. Journal of Fish Diseases 19, 375-387.

Bakke-McKellep, A.M., Press, C.M., Krogdahl, A., Landsverk, T. (2000) Changes in immune and enzyme histochemical phenotypes of cells of the intestinal mucosa of Atlantic salmon (Salmo salar L.) with soybean-meal induced enteritis. Journal of Fish Diseases 23, 115-127.

Bakke-McKellep, A.M., Froystad, M.K., Lilleeng, E., Dapra, F., Refstie, S., Krogdahl, A., Landsverk, T. (2007 a) Response to soy: T-cell-like reactivity in the intestine of Atlantic salmon, Salmo salar L. Journal of Fish Diseases 30, 13-25.

Bakke-McKellep, AM., Penn, M.H., Salas, P.M., Refstie, S., Sperstad, S., Landsverk, T., Ringø, E., Krogdahl, Å. (2007 b) Effects of dietary soybean meal, inulin and oxytetracycline on gastrointestinal histological characteristics, distal intestine cell proliferation and intestinal microbiota in Atlantic salmon (Salmo salar L.). British Journal of Nutrition 97, 699-713.

Barrows, F.T., Bellis, Krogdahl. Å., Silverstain, J.F., Herman, E., Sealey, W.M., Rust, M.B., Gatlin III, D.M. (2008) Report of the plant products in aquafeed strategic planning workshop1: An integrated, interdisciplinary research roadmap for increasing utilization of plant feedstuffs in diets for carnivorous fish. Reviews in Fishery Science 16, 449-455.

Bates, J.M., Mittge, E., Kuhlman, J., Baden, K.N., Cheesman, S.E., Guillemin, K. (2006) Distinct signals from the microbiota promote different aspects of zebrafish gut differentiation. Developmental Biology 297, 374-386.

Birkbeck, T.H., Ringø, E. (2005) Pathogenesis and the gastrointestinal tract of growing fish. In: Holzapfel, W., Naughton, P. (Eds.), Microbial Ecology in Growing Animals. Elsevier, Edinburgh, UK, pp. 208-234.

Bonaldo A., Roem A.J., Pecchini A., Grilli E., Gatta P.P. (2006) Influence of dietary soybean meal levels on growth, feed utilization and gut histology of Egyptian sole (Solea aegyptiaca) juveniles. Aquaculture 261, 580-586.

Bonaldo, A., Roem, A.J., Fagioli, P., Pecchini, A., Cipollini, I., Gatta, P.P. (2008) Influence of dietary levels of soybean meal on the performance and gut histology of gilthead sea bream (Sparus aurata L.) and European sea bass (Dicentrarchus labrax L.). Aquaculture Research 39, 970-978.

Caballero, M.J., Obach, A., Rosenlund, G., Montero, D., Gisvold, M., Izquierdo, M.S. (2002) Impact of different dietary lipid sources on growth, lipid digestibility, tissue fatty acid composition and histology of rainbow trout, Oncorhynchus mykiss. Aquaculture 214, 253-271.

Caballero, M.J., Izquierdo, M.S., Kjørsvik, E., Montero, D., Socorro, J., Fernandez, A.J., Rosenlund, G. (2003) Morphological aspects of intestinal cells from gilthead 
seabream (Sparus aurata) fed diets containing different lipid sources. Aquaculture $225,325-340$.

Caballero, M.J., Gallardo, G., Robaina, L., Montero, D., Fernandez, A., Izquierdo, M. (2006) Vegetable lípid sources affect in vitro biosynthesis of triacylglycerols and phospholipids in the intestine of sea bream (Sparus aurata). British Journal of Nutrition 95, 448-454.

Cai, C-F., Wang, W-J., Ye, Y-T., Krogdahl, Å., Wang, Y-L., Xia, Y-M., Yang, C.-G. (2011) Effect of soybean meal, raffinose and stachyose on the growth, body composition, intestinal morphology and intestinal microflora of juvenile allogynogenetic silver crucian carp (Carassius auratus o $\mathrm{x}$ Cyprinus carpio 3 ). Aquaculture Research early view, doi: 10.1111/j.1365-2109.2011.02811.x

Davies, S.J., Morris, P.C. (1997) Influence of multiple amino acid supplementation on the performance of rainbow trout, Oncorhynchus mykiss (Walbaum), fed soya based diets. Aquaculture Research 28, 65-74.

Dimitroglou, A., Merrifield, D. L., Spring, P., Sweetman, J., Moate, R., Davies, S. J., (2010) Effects of dietary mannan oligosaccharides (MOS) and soybean meal on growth performance, feed utilisation, intestinal histology and gut microbiota of gilthead sea bream (Sparus aurata). Aquaculture, 300, 182-188

Dimitroglou, A., Merrifield, D. L., Carnevali, O., Picchietti, S., Avella, M., Daniels, C. L., Güroy, D., Davies, S. J. (2011) Microbial manipulations to improve fish health and production - a Mediterranean perspective. Fish \& Shellfish Immunology, 30, 1-16.

FAO (2010) Fisheries Global Information System (FAO-FIGIS) - Web site. Fisheries Global Information System (FIGIS). FI Institutional Websites. In: FAO Fisheries and Aquaculture Department [online]. Rome. Updated. http://www.fao.org/fishery/ figis/en"

Gatlin III, D.M., Barrows, F., Brown, P., Dabrowski, K., Gaylord, T.G., Hardy, R.W., Herman, E., Hu, G., Krogdahl, Å., Nelson, R., Overturf, K., Rust, M., Sealey, W., Skonberg, D., Souza, E.J., Stone, D., Wilson, R., Wurtele, E. (2007) Expanding the utilization of sustainable plant products in aquafeeds: a review. Aquaculture Research 38, 551-579.

Gibson, G.R., Probert, H.M., Loo, J.V., Rastall, R.A., Roberfroid, M.B. (2004) Dietary modulation of the human colonic microbiota: updating the concept of prebiotics. Nutrition Research Reviews 17, 259-275.

Gjøen, T., Obach, A., Røsjø, C., Helland, B.G., Rosenlund, G., Hvattum, E., Ruyter, B. (2004) Effect of dietary lipids on macrophage function, stress susceptibility and disease resistance in Atlantic salmon (Salmo salar). Fish Physiology and Biochemistry 30, 149161.

Grisdale-Helland, B., Helland, S.J., Baeverfjord, G., Berge, G.M. (2002) Full-fat soybean meal in diets for Atlantic halibut: growth, metabolism and intestinal histology. Aquaculture Nutrition, 8, 265-270.

Groff, J., LaPatra, S. (2000) Infectious diseases impacting the commercial culture of salmonids. Journal of Applied Aquaculture 10, 17-90.

Harikrishnan, R., Balasundaram C. (2005) Modern trends in Aeromonas hydrophila disease management with fish. Reviews in Fisheries Science 13, 281-320.

Harper, G.M., Dimitroglou, A., Ringø, E., Merrifield, D.L. (2011) Electron microscopy: an important tool to assess the effects of dietary components on the gastrointestinal tract of fish. Asian Aquaculture Network, The Practical, 2, (5), 22-24. 
Heikkinen, J., Vielma, J., Kemilainen, O., Tiirola, M., Eskelinen, P., Kiuru, T., NaviaPaldanius, D., von Wright, A. (2006) Effects of soybean meal based diet on growth performance, gut histopathology and intestinal microbiota of juvenile rainbow trout (Oncorhynchus mykiss). Aquaculture 261, 259-268.

Huber I., Spanggaard B., Appel K.F., Rossen L., Nielsen T., Gram L. (2004) Phylogenetic analysis and in situ identification of the intestinal microbial community of rainbow trout (Oncorhynchus mykiss, Walbaum). Journal of Applied Microbiology 96, 117-132.

Huntington, T., Frid, C., Banks, R., Scott, C., Paramor O. (2004) Assessment of the sustainability of industrial fisheries producing fish meal and fish oil. Report to the Royal Society for the Protection of Birds (RSPB). Poseidon Aquatic Resource Management Ltd., Lymington, Hampshire, UK. June 2004. (http://www.rspb.org.uk/Images/fishmeal_tcm5-58613.pdf).

Kim, D., Brunt. J., Austin, B. (2007) Microbial diversity of intestinal contents and mucus in rainbow trout (Oncorhynchus mykiss). Journal of Applied Microbiology 102, 1654 1664.

Kiron, V., Puangkaew, J., Ishizaka, K., Satoh, S., Watanabe, T. (2004) Antioxidant status and nonspecific immune responses in rainbow trout (Oncorhynchus mykiss) fed two levels of vitamin E along with three lipid sources. Aquaculture 234, 361-379.

Knudsen, D., Urán P., Arnous, A., Koppe, W., Frøkiær H. (2007) Saponin containing subfractions of soybean molasses induce enteritis in the distal intestine of Atlantic salmon. Journal of Agricultural and Food Chemistry 55, 2261-7.

Kraugerud, O.F., Penn, M., Storebakken, T., Refstie, S., Krogdahl, Å., Svihus, B. (2007) Nutrient digestibilities, gut function and morphology in Atlantic salmon (Salmo salar) fed diets where non-starch polysaccharides from soy replace cellulose. Aquaculture 273, 96-107.

Krogdahl, А., Bakke-McKellep, A.M., Røed, K.H., Baeverfjord, G. (2000) Feeding Atlantic salmon Salmo salar L. soybean products: effects on disease resistance (furunculosis), and lysozyme and IgM levels in the intestinal mucosa. Aquaculture Nutrition 6, 7784.

Krogdahl, Å., Bakke-McKellep, A.M., Baeverfjord, G. (2003) Effects of graded levels of standard soybean meal on intestinal structure, mucosal enzyme activities, and pancreatic response in Atlantic salmon (Salmo salar L.). Aquaculture Nutrition 9, 361371.

Krogdahl ̊., Penn, M., Thorsen, J., Refstie, S., Bakke, A.M. (2010) Important antinutrients in plant feedstuffs for aquaculture: an update on recent findings regarding response in salmonids. Aquaculture Research 41, 333-344.

Lesel, R., de la Noüe, J., Choubert, G. (1989) Fecal bacterial flora of rainbow trout under antibiotic treatment: effect of the number of pyloric caeca and the lipid content of food. In: Aquaculture - A Biotechnology in Progress. Vol. 2. pp. 897-903: Eds. De Pauw, N., jaspers, E., Ackerfors, H., Wilkins, N. European Aquaculture Society, Bredane, Belgium.

Lødemel, J.B., Mayhew, T.M., Myklebust, R., Olsen, R.E., Espelid, S., Ringø, E. (2001) Effect of three dietary oils on disease susceptibility in Arctic charr (Salvelinus alpinus L.) during cohabitant challenge with Aeromonas salmonicida ssp. salmonicida. Aquaculture Research 32, 935-945. 
Merrifield, D. L., Bradley, G., Baker, R. T. M., Dimitroglou, A., Davies, S. J. (2009) Soybean meal alters autochthonous microbial populations, microvilli morphology and compromises intestinal enterocyte integrity of rainbow trout (Oncorhynchus mykiss Walbaum). Journal Fish Diseases 32, 755-766.

Merrifield, D.L., Dimitroglou, A., Foey, A., Davies, S.J., Baker, R.R., Bøgwald, J., Castex, M., Ringø, E. (2010) The current status and future focus of probiotic and prebiotic applications for salmonids. Aquaculture 302, 1-18.

Montero, D., Caballero, M.J., Gijon, D., Real, F., Robaina, L. E. \& Izquierdo, M.S. (2006) Influence of dietary blend of vegetable oils on disease resistance and intestinal microbiota of gilthead seabream (Sarus aurata). XII International Symposium on Fish Nutrition and Feeding, May 28th - June 1st, 2006, Biarritz, France

Montero, D., Mathlouthi, F., Tort, L., Afonso, J.M., Torrecillas, S., Fernandez-Vaquero, A., Negrin, D., Izquierdo, M.S. (2010) Replacement of dietary fish oil by vegetable oils affects humoral immunity and expression of pro-inflammatory cytokines genes in gilthead sea bream Sparus aurata. Fish \& Shellfish Immunology 29, 1073-1081.

Romero, J., Navarrete, P. (2006) 16S rDNA-based analysis of dominant bacterial populations associated with early life stages of coho salmon (Oncorhynchus kisutch). FEMS Microbial Ecology 51, 422-430.

Navarrete, P., Espejo, R., Romero, J. (2009) Molecular analysis of microbiota along the digestive tract of juvenile Atlantic salmon (Salmo salar L.). FEMS Microbial Ecology 57, 550-561.

Navarrete, P., Magne, F., Mardones, P., Riveros, M., Opazo, R., Suau, A., Pochart, P., Romero,J. (2010) Molecular analysis of intestinal microbiota of rainbow trout (Oncorhynchus mykiss). FEMS Microbial Ecology 71, 148-156.

Olli, J.J., Krogdahl, Å. (1994) Nutritive value of four soybean products as protein sources in diets for rainbow trout (Oncorhynchus mykiss, Walbaum) reared in fresh water. Acta Agriculturae Scandinavica Section A Animal Science 44, 185-192.

Olli, J.J., Krogdahl, Å., van den Ingh, T.S.G.A.M., Brattås, L.E. (1994) Nutritive value of four soybean products in diets for Atlantic salmon (Salmo salar, L.). Acta Agriculturae Scandinavica Section A Animal Science 44, 50-60.

Olsen, R.E., Ringø, E. (1997) Lipid digestibility in fish: A review. Recent Research Developments in Lipid Research 1, 199-265.

Olsen, R.E., Myklebust, R., Kaino, T., Ringø, E. (1999) Lipid digestibility and ultrastructural changes in the enterocytes of Arctic char (Salvelinus alpinus L.) fed linseed oil and soybean lecithin. Fish Physiology and Biochemistry 21, 35-44.

Olsen, R.E., Myklebust, R., Ringø, E., Mayhew, T.M. (2000) The influences of dietary linseed oil and saturated fatty acids on caecal enterocytes in Arctic char (Salvelinus alpinus L.): a quantitative ultrastructural study. Fish Physiology and Biochemistry 22, 207-216.

Olsen, R.E., Dragnes, B.T., Myklebust, R., Ringø, E, (2003) Effect of soybean oil and soybean lecithin on intestinal lipid composition and lipid droplet accumulation of rainbow trout, Oncorhynchus mykiss Walbaum. Fish Physiology and Biochemistry 29, 181-192.

Oxley, A., Torstensen, B.E., Rustan, A.C., Olsen, R,E. (2005) Enzyme activities of intestinal triacylglycerol and phosphatidylcholine biosynthesis in Atlantic salmon (Salmo salar L.). Comparative Biochemistry and Physiology B 141, 77-87.

Oxley, A., Jutfelt, F., Sundell, K., Olsen, R.E. (2007) Sn-2-monoacylglycerol, not glycerol, is preferentially utilised for triacylglycerol and phosphatidylcholine biosynthesis in 
Atlantic salmon (Salmo salar L.) intestine. Comparative Biochemistry and Physiology B $146,115-123$.

Rawls, J.F., Samuel, B.S., Gordon, J.I. (2004) Gnotobiotic zebrafish reveal evolutionarily conserved responses to the gut microbiota. Proceedings of the National Acadamey of Science USA 101, 4596-4601.

Refstie, S., Sahlstrom, S., Brathen, E., Baeverfjord, G., Krogedal, P. (2005) Lactic acid fermentation eliminates indigestible carbohydrates and antinutritional factors in soybean meal for Atlantic salmon (Salmo salar). Aquaculture 246, 331-345.

Refstie, S., Landsverk, T., Ringø, E., Sundby, A., Shearer, K.D., Kroghdahl, Å. (2006) Digestive responses of 1- and 2-year-old Atlantic cod (Gadus morhua) fed standard or bioprocessed soybean meal. Aquaculture 261, 269-284.

Ringø, E., Birkbeck, T.H. (1999) Intestinal microflora of fish larvae and fry. Aquaculture Research 30, 773-789.

Ringø, E., Olsen, R.E. (1999) The effect of diet on aerobic bacterial flora associated with intestine of Arctic charr (Salvelinus alpinus L.). Journal of Applied Microbiology 86, 22 28.

Ringø, E., Olsen, R.E. (2008) Gut health in aquatic species, In: World Nutrition Forum. The Future of Animal Production, Binder, E.M., Schatzmayr, G (eds), 79-105, Nottingham University Press, ISBN: 978-1-904761-80-8, Nottingham, UK.

Ringø, E., Strøm, E., Tabachek, J-A. (1995) Intestinal microflora of salmonids: a review. Aquaculture Research 26, 773-789

Ringø, E., Lødemel, J.B., Myklebust, R., Kaino, T., Mayhew, T.M., Olsen, R.E. (2001) Epithelium associated microbes in the gastrointestinal tract of Arctic charr (Salvelinus alpinus L.). An electron microscopical study. Journal of Applied Microbiology 90, 294-300.

Ringø, E., Lødemel, J.B., Myklebust, R. Jensen, L., Lund, V., Mayhew, T.M., Olsen, R.E. (2002) Effect of soybean, linseed and marine oils on aerobic gut microbiota of Arctic charr Salvelinus alpinus L. before and after challenge with Aeromonas salmonicida ssp. salmonicida. Aquaculture Research 33, 591-606.

Ringø, E., Olsen, R.E., Mayhew, T.M., Myklebust, R. (2003) Electron microscopy of the intestinal microflora of fish. Aquaculture 227, 395-415.

Ringø, E., Sperstad, S., Myklebust, R.., Refstie, S., Krogdahl, ^̊. (2006) Characterisation of the microbiota associated with the intestine of Atlantic cod (Gadus morhua L.). The effect of fish meal, soybean meal and a bioprocessed soybean meal. Aquaculture 261, 829-841.

Ringø, E., Myklebust, R., Mayhew, T.M., Olsen, R.E. (2007) Bacterial translocation and pathogenesis in the digestive tract of larvae and fry. Aquaculture 268, 251-264.

Ringø, E., Sperstad, S., Kraugerud, O.F., Krogdahl, А (2008) Use of $16 \mathrm{~S}$ rRNA gene sequencing analysis to characterise culturable intestinal bacteria in Atlantic salmon (Salmo salar) fed diets with cellulose or non-starch polysaccharides from soy. Aquaculture Research 39, 1087-1100.

Ringø, E., Løvmo, L., Kristiansen, M., Bakken, M., Salinas, I., Myklebust, R., Olsen, R.E., Mayhew, T.M. (2010 a) Lactic acid bacteria vs. pathogens in the gastrointestinal tract of fish: a review. Aquaculture Research 41, 451-467.

Ringø E., Olsen, R.E., Gifstad, T.Ø., Dalmo, R.A., Amlund, H., Hemre, G.-I., Bakke, A.M. (2010 b) Prebiotics in aquaculture: a review. Aquaculture Nutrition 16, 117-136. 
Rombout J.H.W.M., Abelli, L., Picchietti, S., Scapigliati, G., Kiron, V. (2011) Teleost intestinal immunology early view. Fish $\mathcal{E}$ Shellfish Immunology (2010), doi:10.1016/ j.fsi.2010.09.001

Romarheim, O.H., Zhang, C., Penn, M., Liu, Y.-L., Tian, L.-X., Skrede, A., Krogdahl, Å., Storebakken, T. (2007) Growth and intestinal morphology in cobia (Rachycentron canadum) fed extruded diets with two types of soybean meal partly replacing fish meal. Aquaculture Nutrition 13, 1-7.

Rumsey, G.L., Siwicki, A.K., Anderson, D.P., Bowser, P.R. (1994) Effect of soybean protein on serological response, non-specific defense mechanisms, growth, and protein utilization in rainbow trout. Veterinary Immunology and Immunopathology 41, 323339.

Spanggaard, B., Huber, I., Nielsen, J., Nielsen, T., Appel, K.F., Gram L. (2000) The microflora of rainbow trout intestine: a comparison of traditional and molecular identification. Aquaculture 182, 1-15.

Suyehiro, Y. (1942) A study on the digestive system and feeding habits of fish. Japanese Journal of Zoology 10, 1-303.

Tacon, A. (2010) Trends in global Aquaculture and Production. Asian Aquaculture, The Practical. Vol. 2, Issue 1, Jan-March 2011, pp 11-12. Asian Aquaculture Network, The Practical 2(1), 11-12.

Urán, P.A., Gonçalves, A., Taverne-Thiele, J.J., Schrama, J.W., Verreth, J.A.J., Rombout, J.H.W.M. (2008 a) Soybean meal-induced enteritis in common carp (Cyprinus carpio L.) and the gene expression of inflammatory mediators in intestinal leukocytes. Fish \& Shellfish Immunology 25, 751-60.

Urán, P.A., Aydin, R., Schrama, J.W., Verreth, J.A.J., Rombout, J.H.W.M. (2008 b) Soy bean meal induced uptake block in the distal enterocytes of Atlantic salmon (Salmo salar L.). Journal of Fish Biology 73, 2571-9.

van den Ingh, T.S.G.A.M., Krogdahl, A., Olli, J., Hendricks, H.G.C.J.M., Koninkx, J.F.J.G. (1991) Effects of soybean-containing diets on the proximal and distal intestine in Atlantic salmon (Salmo salar): a morphological study. Aquaculture 94, 297-305

van den Ingh, T.S.G.A.M., Olli, J.J., Krogdahl, A. (1996) Alcohol-soluble components in soybeans cause morphological changes in the distal intestine of Atlantic salmon, Salmo salar L. Journal of Fish Diseases 19, 47-53.

Waagbø, R., Sandnes, K., Jørgensen, J., Engstad, R., Glette, J., Lie, Ø. (1993) Health aspects of dietary lipid sources and vitamin E in Atlantic salmon (Salmo salar). II. Spleen and erythrocyte phospholipid fatty acid composition, nonspecific immunity and disease resistance. Fiskeri Direktoratets Skrifter Serie Ernæring 6, 63-80. 


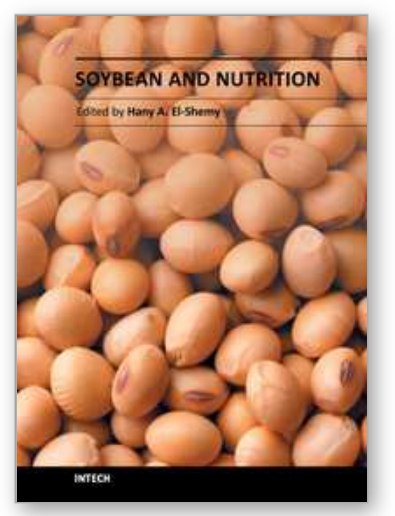

\author{
Soybean and Nutrition \\ Edited by Prof. Hany El-Shemy
}

ISBN 978-953-307-536-5

Hard cover, 476 pages

Publisher InTech

Published online 12, September, 2011

Published in print edition September, 2011

Worldwide, soybean seed proteins represent a major source of amino acids for human and animal nutrition. Soybean seeds are an important and economical source of protein in the diet of many developed and developing countries. Soy is a complete protein and soy-foods are rich in vitamins and minerals. Soybean protein provides all the essential amino acids in the amounts needed for human health. Recent research suggests that soy may also lower risk of prostate, colon and breast cancers as well as osteoporosis and other bone health problems and alleviate hot flashes associated with menopause. This volume is expected to be useful for student, researchers and public who are interested in soybean.

\title{
How to reference
}

In order to correctly reference this scholarly work, feel free to copy and paste the following:

Daniel L. Merrifield, Rolf Erik Olsen, Reidar Myklebust and Einar Ringø (2011). Dietary Effect of Soybean (Glycine max) Products on Gut Histology and Microbiota of Fish, Soybean and Nutrition, Prof. Hany El-Shemy (Ed.), ISBN: 978-953-307-536-5, InTech, Available from: http://www.intechopen.com/books/soybean-andnutrition/dietary-effect-of-soybean-glycine-max-products-on-gut-histology-and-microbiota-of-fish

\section{INTECH}

open science | open minds

\section{InTech Europe}

University Campus STeP Ri Slavka Krautzeka 83/A 51000 Rijeka, Croatia Phone: +385 (51) 770447

Fax: +385 (51) 686166 www.intechopen.com

\section{InTech China}

Unit 405, Office Block, Hotel Equatorial Shanghai

No.65, Yan An Road (West), Shanghai, 200040, China 中国上海市延安西路65号上海国际贵都大饭店办公楼 405 单元 Phone: +86-21-62489820

Fax: +86-21-62489821 
(C) 2011 The Author(s). Licensee IntechOpen. This chapter is distributed under the terms of the Creative Commons Attribution-NonCommercialShareAlike-3.0 License, which permits use, distribution and reproduction for non-commercial purposes, provided the original is properly cited and derivative works building on this content are distributed under the same license. 